https://doi.org/10.1590/198053146109

\title{
READING AND WRITING IN EARLY CHILDHOOD EDUCATION: CONTEXTS AND PRACTICES UNDER DEBATE
}

\author{
Maria Fernanda Rezende Nunes' \\ Patrícia Corsino" \\ TRANSLATED BY Deyse Assis de Miranda"l
}

\begin{abstract}
The article reports an analysis of interviews and observations carried out in 27 schools by the research team in charge of project "Boas práticas de leitura e escrita na educação infantil" [Good reading and writing practices in Early Childhood Education], which encompasses 7 counties in different Brazilian regions. Good practices are the ones in which childhood and experience, education and care are creation binomials based on the Diretrizes Curriculares Nacionais para a Educação Infantil [National Curriculum Guidelines for Early Childhood Education] (DCNEI - 2009). The article introduces the profile of the assessed schools and analyzes the observation records according to space and materials and interaction and interlocution categories. Based on the results, it is essential to seek an identity for early childhood education based on the dialogic way teachers listen and respond to children. Ludicsymbolic practices prevail in daycare centers, whereas these practices are added with more directive practices in pre-schools, which are substantiated by contents linked to literacy.
\end{abstract}

EARLY CHILDHOOD EDUCATION • READING • WRITING • EDUCATIONAL PRACTICES

\section{LEITURA E ESCRITA NA EDUCAÇÃO INFANTIL: CONTEXTOS E PRÁTICAS EM DIÁLOGO}

\section{Resumo}

O artigo analisa relatórios de entrevista e observação de 27 escolas e turmas da pesquisa "Boas práticas de leitura e escrita na educação infantil”, em sete municípios de regiões brasileiras. Boas práticas são aquelas nas quais infância e experiência, educação e cuidado constituem binômios de criação, conforme as Diretrizes Curriculares Nacionais para a Educação Infantil (DCNEI) 2009. Apresenta-se um perfil das escolas e são analisados os registros de observação segundo as categorias espaços e materiais e interações e interlocuções. Revela-se, nas conclusões, a busca de uma identidade para a educação infantil, na forma dialógica como as professoras escutam e respondem às crianças. Na creche, predominam práticas de cunho lúdico-simbólico, enquanto na pré-escola estas ainda convivem com outras mais diretivas, pautadas em conteúdos relacionados à alfabetização.

EDUCAÇÃO INFANTIL • LEITURA • ESCRITA • PRÁTICAS EDUCATIVAS

I Universidade Federal do Estado do Rio de Janeiro (Unirio), Rio de Janeiro (RJ), Brazil; https://orcid.org/0000-0003-3696-9369; nunes.mariafernandarezende@gmail.com

II Universidade Federal do Estado do Rio de Janeiro (Unirio), Rio de Janeiro (RJ), Brazil; https://orcid.org/0000-0003-4623-5318; corsinopat@gmail.com

III Good Deal Consultoria Linguística, Juiz de Fora (MG), Brazil; deyse@gooddealconsultoria.com 


\section{LECTURE ET ÉCRITURE DANS L'ÉDUCATION DE LA PETITE ENFANCE: MISE EN DIALOGUE DES CONTEXTES ET DES PRATIQUES}

\section{Résumé}

Cet article analyse des rapports d'entretiens et d'observation de 27 classes de differentes écoles dans le cadre de la recherche sur les "Boas práticas de leitura e escrita na educação infantil" [Bonnes pratiques de lecture et d'écriture dans l'éducation de la petite enfance], menée dans sept communes de plusieurs régions brésiliennes. Les bonnes pratiques sont celles où enfance et expérience et éducation et soins constituent des binômes de création, conformément aux Diretrizes Curriculares Nacionais para a Educação Infantil (DCNEI - 2009) [Lignes Directrices du Programme National pour l'Éducation de la Petite Enfance]. Un profil des écoles est dressé et les comptes rendus d'observation en fonction des catégories espaces et matériaux et interactions et interlocutions sont analysés. Les conclusions révèlent une quête d'identité pour l'éducation de la petite enfance dans la forme dialogique avec laquelle les enseignants écoutent et répondent aux enfants. Les pratiques ludiques et symboliques prédominent dans les crèches tandis que dans les maternelles elles coexistent avec des pratiques plus directives, basées sur les contenus de l'alphabétisation.

ÉDUCATION DE LA PETITE ENFANCE • LECTURE • ÉCRITURE • PRATIQUES ÉDUCATIVES

\section{LECTURA Y ESCRITURA EN LA EDUCACIÓN INFANTIL: CONTEXTOS Y PRÁCTICAS EN DIÁLOGO}

\section{Resumen}

El artículo analiza informes de entrevista y observación de 27 escuelas y grupos de la investigación "Boas práticas de leitura e escrita na educação infantil” [Buenas prácticas de lectura y escritura en la educación infantil], en siete municipios de regiones brasileñas. Las buenas prácticas son aquellas en las que la infancia y la experiencia, la educación y el cuidado constituyen binomios de creación, conforme a las Diretrizes Curriculares Nacionais para a Educação Infantil [Directrices Curriculares Nacionales para la Educación Infantil] (DCNEI - 2009). Se presenta un perfil de las escuelas y se analizan los registros de observación según las categorías espacios y materiales e interacciones e interlocuciones. Se revela, en las conclusiones, al buscar una identidad para la educación infantil, en la forma dialógica, como las profesoras escuchan y responden a los niños. En la guardería, predominan prácticas de cuño lúdico-simbólico, mientras que en la preescolar éstas todavía conviven con otras más directivas, basadas en contenidos relacionados con la alfabetización. 
What I have observed and sensed in children (and in me), as the reflex of our work, is great enthusiasm; challenges have been faced with happiness and joy. It gives us the certainty that the search for knowledge in children's opinion is not the preparation for anything, but for life, for here and now.' (FREIRE, 1983, p. 50, own translation)

ADALENA FREIRE, WHO DEVELOPED AN ARTICULATED STUDY BASED ON CHILDREN'S interest at the late 1970s, concluded her report and stated that the search for knowledge by children lies on "here and now". It is not the preparation for anything, she stated, when she answered to what had been exposed as the purpose of pre-school. The novelty of her report, which is registered in the book Paixão de conhecer o mundo [Passion to know the world], is highlighted by the concepts of childhood and early childhood education. These concepts have allowed a new and challenging study experienced with enthusiasm in a time-space wherein stories were gathered and collectively mixed. The report is currently read along with questions that echo: How does the set of educational practices in a pre-school class can articulate children's knowledge and experiences such as knowledge about the cultural, artistic, environmental, scientific and technological patrimony in a significant, ludic, relational and participatory way, based on happy and joyful experiences? What can early childhood education trigger in the very pulse of the 'here and now' experience lived by children and teachers? 
We understand that such dynamics is the space and time of deviation, of the movement to disrupt what is pre-established and idealized. It concerns displacements that include welcoming the unpredictable and the unusual. This movement is characteristic of interactions, of the interlocution of pronounced and heard voices that, therefore, can take place either in the educational process or in trajectories taken by research in the human sciences field.

The aim of the present article is to analyze the interviews and observations carried out in 27 school and early childhood education classes by the research group in charge of the project "Good reading and writing practices in early childhood education”, which takes place in Recife/Pernambuco (PE), Natal/Rio Grande do Norte (RN), Campo Grande/Mato Grosso do Sul (MS), Belo Horizonte/ Minas Gerais (MG) and Lagoa Santa/MG and Porto Alegre/Rio Grande do Sul (RS) counties - the study is part of an inter-institutional project. ${ }^{2}$ Good practices are herein understood as the ones in which childhood and experience, and education and care are the creation binomials defined by the National Curriculum Guidelines for Early Childhood Education (BRASIL, 2009), which takes the risk of value judgements.

The essay "A palavra na vida e a palavra na poesia” [The word in life and the word in poetry] by Volochínov (2013) gives special relevance to value judgement. According to the bakhtinian author, value judgement in the extra-verbal discourse is only understood by a certain group. Therefore, it ends up becoming dogmatic, because in this community, it is seen as ultimate and, so, it does not enable replicates. However, when it is pronounced, verbalized and justified, it becomes questionable and can be argued. Accordingly, we aim at disclosure what has been understood as good practices, at analyzing their production conditions in order to discuss questions that argue educational policies and practices focused on the quality of the provided early childhood education.

Rosemberg (2015), by discussing public policies and the quality of early childhood education, analyzes how old the debate about quality in education is it has been part of early childhood education even before it had a formal name or before it became the object/subject of research and policies. This author evidences the mismatch between real and ideal and between all that has been conquered so far, although there is always another path possible to be taken. Talking about quality, says Rosemberg, means facing stress within a scenario where the debate and concepts about the topic are advanced, but centered in a yet unequal and antidemocratic society that discriminates individuals due to economic, racial, regional, locational and age reasons - such discrimination affects children, mainly babies, in school units. She points out the presence of topic 'quality' in official Education Ministry documents since 1993, such as in Política de educação infantil [Early Childhood Education Policy]. This policy states that, among other goals, it is essential "improving the quality of assistance provided in daycare centers and in pre-school” (BRASIL, 1993, p. 21). This document triggered many

2 This research is a sub-project of inter-institutional research "Reading and writing in Early Childhood Education", developed from 2014 to 2018 by researchers from Universidade Federal de Minas Gerais (UFMG), UFRJ and Unirio. 
responses, among which one finds Consulta nacional sobre a qualidade da educação infantil [National Consultation on the Quality of Early Childhood Education] stands out (CAMPOS; CRUZ, 2006), besides the studies, research and seminars about the quality of evaluation in early childhood education (BRASIL, 2015; SOUZA; MORO; COUTINHO, 2015; CAMPOS, 2013).

That is the way how the expected quality faces contradictions and mismatches by meeting the objective conditions of an equal society. We remain alert to such issue and acknowledge that each school deals with its own social reality, just as the actors who take part of it. As highlighted by Bourdieu (2009), no knowledge is transcendent, but historical; it derives from certain experiences. Replications are updated at different historical and political moments. By understanding that quality is a polysemic concept crossed by the historicalcultural context, the aim of our study was to shine light on singular experiences and feelings from teachers who work with daycare and pre-school classes, mainly with written language.

The reading/writing topic has been living in the universe of teachers, families, children, teaching systems and legislations for quite a long time. Many research fields have joined the political debates due to different goals, but they have also dedicated their efforts to child literacy, to children reading and writing skills. Contrasting viewpoints seek room in research, policies and practices; therefore, this process demands reasoning by teachers and the recovery of conquers and positions. For example, we can mention that, some waves in Brazil have been watering school routines at different intensities, depending on the context and on the involved actors, such as debates about methods back in the 1970s; theory of psychogenesis of written language, which is based on the constructivist concept by Emilia Ferreiro in the 1980s and 90s; matters related to literacy and school; and the period known as "literacy reinvention" in the 2000s, which is back on the main stream of methodological discussions about the theme.

The same can be said about early childhood education, which shows different relationships with elementary school. These relationships go from the search for specific functions and practices, to the submission to contents and methodologies applied to elementary education. Child reading and writing practices in early childhood education in contemporary society embody most of these disputes, either due to the value given to literacy - because of the 'grafocentric' bias organizing it - or to the concept of productivity, of freetime shortening and of the demand for outcomes that prove the return from investments made in it.

The present article is an analysis of interviews and observations carried out in 27 schools and early childhood education classes from the public education network. These schools have been developing practices that, explicitly or implicitly, express consensus in the early childhood education field (BRASIL, 2009). The first section of the text introduces the stages of these practices and the choices made to identify and analyze early childhood education school belonging 
to the public network that has been developing good reading and writing practices, as well as the involved actors and adopted instruments used in these practices. The second section draws the profile of school units that develop reading and writing practices that are seen as capable of tightening the educational process, as well as show the features of a set of schools and pedagogical teams. Next, the text draws the analysis of records in observation reports based on two categories, namely: spaces and materials, and interactions and interlocutions. Finally, the article exposes considerations about the universe observed in this environment and points out traces of the identity that has been built in the reading and writing field in Brazil's early childhood education, within the context of mandatory school enrollment at the age of four.

\section{THE RESEARCH: STAGES AND CHOICES}

The inter-institutional project found out that the education field carried out 139 research (60\% of academic production in the country) during a literature review about academic production on literacy. In total, $80 \%$ of these studies were carried out in the last decade. This finding highlights the gaps and lack of continuity in scientific production and the earliness of more substantial research about this topic in academic investigations, a fact that raises questions due to the expansion of this research field and to the increase in pre-school universalization targets. Thus, we argue: how has been the articulation of these studies with teachers' training and with pedagogic practices? Research in the education field (KRAMER; NUNES; CORSINO, 2011) has been evidencing the institutional trend of strong preparation, mainly in pre-school. But, would this submission and pressure bias in elementary school also be included in practices complemented as good by education secretariats, school principals and teachers?

By taking into account that analytical concepts are built from discourses and are not an a priori factor of such discourses, it is possible stating that the methodological procedures applied to the investigations seek knowing the perceptions about good reading and writing practices in early childhood education and the perception by different actors involved in them (who are women, given the profile of the education field, itself). These actors also include the ones accounting for early childhood education in municipal education bureaus, namely: indicated school principals, teachers and, yet, the research group (professors in public universities). These professors were selected because they carry out research in the early childhood education and/or literacy and reading and writing fields in different Brazilian fields. The awareness of territorial inequalities in the country motivated the option to include schools from different regions in the country and from different neighborhoods in the investigated state capital.

The research counted on five stages; the first one was based on a meeting to trigger the discussions, to meet the team and to analyze the instruments elaborated by the project coordination team - interview scripts and observation protocols. After the instruments were validated, researchers started the field study 
in the counties. Members of the Municipal Education Department from NatalRN, Recife-PE, Campo Grande-MS, Belo Horizonte-MG, Lagoa Santa-MG and Porto Alegre-RS counties were interviewed in the second stage of the study. Researchers asked for daycare and pre-school unit nominations from municipal bureaus; these units had to be developing good reading and writing practices. Each researcher interviewed principals from five early childhood education institutions in the third research stage, which were selected in the first stage of it (except for Porto Alegre, where interviews were carried out with six principals, and for Minas Gerais, which added a school from Lagoa Santa to the sample). Teachers were interviewed in the fourth stage of the research - all of them were nominated by the schools' direction boards -, they worked with different age groups in early childhood education (27 interviews were made, in total). The fifth stage lied on observing the education practices of the interviewed teachers. ${ }^{3}$ Finally, a seminar with researchers and interviewees (members of education departments, school principals and teachers) was organized. The seminar made it possible socializing and debating about research results. In order to assure unity among five regional teams, we opted to follow structured scripts that were previously qualitatively and quantitatively analyzed.

We point out that the project coordination team focused on developing a field research manual, which comprised the "good practice" principles. The literature review on reading and writing in early childhood education, the studies developed by the project researchers, as well as legal and regulating documents of Ministério da Educação (MEC) (Article 9 of DCNEI, 2009) were the very basis of such definition. The aim was to create an environment to exchange concepts and practices on reading and writing in early childhood education with the researchers and to seek consensus. Good practices were understood as the ones that:

- Concern a sequence of activities supported by goals, which are continuous and result in outcomes substantiated by group/class interactions;

- Take place constantly and continuously and that link class routines to the institution's routines; it is an isolated activity, although interesting, but it is also a consistent pedagogical proposition;

- Present a dialogic integration between adults and children; in other words, it is a real discursive process, in which teachers welcome what is brought in by the children based on alert and interested hearing that answers to the call and is changed by it;

- Face interactions and playing as working axes. Dialogic interactions and playing are understood as the main child cultural element, rather than reduce them into a learning/teaching strategy;

3 A guiding script was elaborated for the observations, it held questions about spaces, materials, routines, practices and children interaction to each other, to teachers and to the proposition in course. Pictures were also important instruments, but they were not taken as events due to ethical reasons, since they had children in them. 
- Encourage children to talk about themselves, a fact that enables experiencing the narratives about lived, imagined or created situations;

- The written language takes place in an integrated and balanced way in comparison to oral language and other forms of expression;

- Reading and writing happen in real and significant situations, i.e., they must be inserted in social practices and in interactive situations that are, therefore, necessary for communication between interlocutors;

- Favor children's insertion in the literate culture due to the experience of living with different supports, and oral and written discursive genres;

- Understand language within a discursive perspective, which is closely related to thinking and awareness; therefore, they are part of the individual, rather than just a mere tool or work field.

Interview scripts and observation protocols comprised open and closed questions, as well as photographic records. The closed answers were tabulated, and the open ones were organized into events and grouped into collections. According to Bakhtin (1992), the research event is a fragment capable of summarizing a unit of meaning and to assure the enunciative context. It is a cut of records that comprise categories and collections that allow learning and giving new meanings to recorded situations when they are grouped by affinity.

The next section introduces a panorama of schools that have participated in the current study, it approaches their working conditions, interviewees' profile and the collective actions taken by school principals and teachers.

\section{SCHOOLS, CONTEXTS AND TRAINING}

Scrip analyses allowed drawing the profile of units that have been developing reading and writing practices that mobilize the education process. It showed the features and trends of a set of schools and pedagogical teams based on quantifiable requirements, such as school opening date, functioning features and regime, assistance stages, professional profile, employment relationships, time as a teacher, besides planning, registration and performance feedback conditions.

With respect to the beginning of the activities, $65 \%$ of the investigated institutions were launched in 2005, i.e., they have been working for more than 10 years, a fact that evidences a work trajectory based on early childhood education. As for specificity, $80 \%$ of these schools are exclusive for early childhood education, in other words, they work with daycare and pre-school, only. But, in some cases, the daycare cycle in not complete, since it just accepts children from one to two years old. The highest subscription rate $(55.9 \%$ of the total of investigated schools) concerns children in the age group 49 months or older (four years old or older). Children in the age group 2 years or younger account for $11.5 \%$ of the subscriptions. When it comes to assistance shifts, the greatest offer of full-time 
shift schools (70\%) regard children in the age group 0-3 years, and most children between 4 and 6 years old only have part-time shift schools (60\%). These data corroborate the trend to concentrate attention to early childhood education in pre-school (ABRAMOWICZ; TEBET, 2017), whereas daycare focuses on full-time shifts (ARAÚJO, 2015).

With regards to the employment relationship of school principals, pedagogical coordinators and teachers, one can observe that almost all of them were hired through public tenders. It is the very opposite of what is observed in the case of most assistants working in daycare centers. Campos (1994, 2013), based on a research conducted throughout the last three decades, showed how daycare professionals were historically qualified in a non-integrated way: job descriptions are undefined and/or focused on smaller importance or non-pedagogical factors, similar functions have different nomenclatures - all these features weaken what would be known as a precarious work or professional category.

All school principals have a college major and $77 \%$ of them have a postgraduation degree, Master or $\mathrm{PhD}$ degree. The same happens with coordinators and teachers, since most of them have a major in Pedagogy, and post-graduation degrees. Therefore, we are talking about a highly qualified group of professionals whose qualification is above the national average. Based on data by the 2017 School Census, $66.4 \%$ of teachers working in daycare centers have a college major, as well as $68 \%$ of the ones working in pre-schools.

School principals are not young, $87.5 \%$ of them are in the age group 41 years and older. We did not find principals younger than 30 years old. All interviewed teachers were woman and most of them $(90.9 \%)$ were in the age group $31-50$ years. We did not interview any teacher younger than 30 years old or older than 60 years.

Regarding expertise, almost all the investigated teachers had been teaching for more than 10 years (81.5\%), except for the ones working in Mato Grosso do Sul State, where this index dropped to $50 \%$ In total, $77.8 \%$ of the ones working with early childhood education had been teaching for more than 6 years.

Concerning work shifts, $77.8 \%$ of the interviewed teachers work full shifts, $62 \%$ of them in the same institution. Teachers in Pernambuco State stand out because $83.3 \%$ of them work full shift in the same school. About teachers' expertise, most of them have already performed other functions in a different school (70.4\%). The fraction of teachers who have worked as pedagogical coordinators is significant $(25.9 \%)$, some of them were school principals in the past (7.4\%). The percentage of teachers in Rio Grande do Norte State who have worked as pedagogical coordinators is outstanding (80\%).

Based on these data, it is possible to get some important elements to subsidize the development of good practices, namely: a stable team of teachers, professionals hired through public tenders and graduated in Pedagogy (some have post-graduation degree), good expertise or professionals investing in best qualification, professionals working more than one shift in the same institution, besides units specific for daycare and pre-school assistance. 
All teachers said they like reading when they were asked about the habit of reading. Moreover, $63 \%$ of them find time to read, they said to be always reading something. The same was not observed with $37 \%$ of the teachers who stated not to find time to read. Similar to other studies (FANFANI, 2007; ANDRADE et al., 2004; CORSINO, 2003), books about pedagogy and education are the most often read ones (85.2\%), although literature accounts for a significant percentage (74.1\%). Religious books account for $30 \%$ of the reading demands and biographies account for $25 \%$ of them.

With respect to the mean number of students per class, except for schools in Campo Grande-MS whose mean number of students per class was 26 -, in all other schools the mean number of students per class was lower than 20; Natal recorded 14 students per class, on average. It is important highlighting that the work developed by the teachers is often performed with the help of an assistant (70.4\%); only few teachers count on the help of another teacher (7.4\%). These numbers correspond to an adult/children proportion quite favorable for personal and collective attention and for space and materials organization.

All schools in the present research have pedagogical propositions, most of them (85.2\%) have a ready and synthesized proposition, the remaining ones (14.8\%) are still elaborating their propositions. Teachers participated in pedagogical proposition elaboration in most of the assessed schools (73.9\%).

Collective meetings for planning and evaluation were essential for discussions and reflections about the study. They took place in almost all schools, except for one of them. The meetings often happened once a week (34.6\%) and on a monthly basis (30.8\%), they were biweekly in $19.2 \%$ of the schools. Based on the interviews, there were collective study meetings in most of the investigated schools (88.5\%). Most participants in these meetings were school principals (70.4\%), teachers (70.4\%) and pedagogical coordinators (55.6\%). Technicians or other employees from the Education Department, as well as consultants, also participated in a few meetings, but children and parents were invited to participate in them. The participation of consultants in these meetings in $40 \%$ of the assessed schools in Minas Gerais State is noteworthy.

School principals or pedagogical coordinators observed and evaluated the activities developed by teachers and assistants with children in almost all assessed schools (96.3\%). Teachers report the activities they had developed with their daycare and pre-school classes in almost all schools (96.3\%).

Briefly, teachers' work conditions, school infrastructure, investment in qualification - in group or in the institution itself -, the presence of a collective project based on elaborated pedagogical propositions and follow-ups on teachers' activities point towards an environment favorable for the development of highquality practices. However, several aspects pressure and make day routines complex, since childhood, early childhood education, language and literacy concepts get connected and dispute different places; these aspects will be addressed in the following section. 


\section{PRACTICES IN QUESTION}

By analyzing the observation reports and the pictures taken from the assessed classes, we divided the events into two great interrelated collections, namely: spaces and materials, and interactions and interlocutions. The separation between two collections is a way to emphasize the most specific features of each group, as well as the concepts linked to them. Bondioli and Montovani (1998) state that spaces and materials embody meanings and trigger continuous interactions that cover affection aspects, and social and symbolic experiences lived from them (space and materials). Environment is conceived as a process, since it continuously changes due the effects of actions, hopes and relationships of individuals acting in it. Such changes influence the actions of these individuals. The organization of school and class spaces, furniture and all sorts of materials bring along the marks of actions taken by these individuals and concern the interactions and interlocutions that can happen. They also regard values and conceptions that drive people circulating in this environment because, according to Bakhtin (1992), reality is 'signic', and all physical bodies and artistic-symbolic images are an ideological product; therefore, there is an intense debate distinguishing contexts from practices. Accordingly, we will analyze the events of the two collections in the next section in order to trigger a discussion about good reading and writing practices in early childhood education.

\section{SPACES AND MATERIALS}

Based on records about spaces in the observed, described and photographed schools, one can observe that children have access to the internal and external areas in most of them. Almost all classrooms have flexible organization, they can deal with different arrangements, they allow children to develop collective and differentiated activities in a simultaneous way - along or in small groups - and to have plenty of room to play. Many spaces in the classrooms are organized in their corners, they count on shelves to expose the class' materials, and children have easy access to them. Most classrooms also have a mirror and high and/or low closed cabinets for exclusive use by teachers. Concerning pedagogical material types, all classes had toys and board games, almost all of them had books and materials for artistic activities (81.5\% of the classrooms), more than half of them have magazines and cartoons (63.0\%) and some even count on costumes (40.7\%). This brief description shows that most of the nominated schools had good reading and writing practices in early childhood education, besides presenting a basic infrastructure capable of supporting their propositions.

The following events highlight space materiality and the actions taken by teachers to organize and create possibilities and to reinvent the functions of furniture and objects to encourage the interaction of children with them. These 
reports ${ }^{4}$ point towards a feature that has prevailed in the 27 classes, they indicate what has been understood as good practices.

When it comes to spaces reserved for babies and small children, there were reports evidencing a sensitive sight over material organization and distribution:

There are cradles positioned in such a way in the classroom to create obstacles, paths and ways. Materials are diversified and placed on the reach of the babies. ${ }^{5}$ (B3, own translation)

The classroom area as a whole is organized to allow babies' autonomous action and the interaction between them, there are not cradles and the babies can circulate freely through the classroom. There are toys and materials constantly produced by the teachers on the floor, and teachers encourage the meeting with the babies, depending on the interest shown by the baby. Teachers also make interventions, whenever necessary, to favor interactions started by the babies. When teachers talk to the babies, they encourage their playing and object exploration, a fact that ends up calling the attention of other babies, and it makes the interaction between them easier. ${ }^{6}$ (E1, own translation)

We also observed that the space reserved to the class in most of the assessed schools is mutable. Depending on the proposition, the teacher organizes and reorganizes the space in order to support and encourage children's playing, as it can be observed in the next report:

The teacher assembles a tent in the classroom for children to play cave. Besides, the teacher follows children's moves, i.e., she observes and supports children's play such as when she took a mattress or fabric piece to be the bed of a group of children playing mammy, they would feed the doll, go to the supermarket, and so on. The monitor observed the boy and helped him assembling what would initially be a car with a chair. They placed chairs one by the other, the monitor said that she was going to find a wheel to the car. The car

4 The observation reports in the scope of the present study were divided by state and school, based on letters and numbers, respectively.

5 In the original: "Há, na sala, berços virados com o objetivo de criar obstáculos, caminhos e cantinhos. Os materiais são diversificados e ao alcance dos bebês."

6 In the original: "O espaço da sala como um todo é organizado para promover a ação autônoma dos bebês e a interação entre eles, não há berços e os bebês circulam livremente pela sala. Nas paredes e no chão há brinquedos e materiais produzidos constantemente pelas educadoras, os quais promovem encontros dos bebês a partir do interesse despertado pelos objetos. Nesses momentos, observou-se, também que as educadoras intervêm, quando oportuno, favorecendo a interação já iniciada pelos bebês. Quando conversam com eles, alimentando brincadeiras e exploração de objetos, acabam promovendo a aproximação de outros bebês, facilitando a interação entre eles." 
became a bus and other children came to play with them. The boy who had created the game said that he was going downtown, that they had to hurry up. ${ }^{7}$ (E3, own translation)

Nursery room has toys and books (bought and produced by the teachers) to stimulate children's senses (to explore sounds, color, textures and shapes). Children explore these materials freely or together with other classmates. There is a carpet on the floor, as well as cushions and a buoy to encourage children to move around. ${ }^{8}$ (D2, own translation)

These practices promote different interactions, substantiate conversations between teachers and children, as well as point out that "they are adapted and have active participation, they are always telling something they recall, that has happened, or that they are working with"9 (E3, own translation). Although in a smaller sphere, there were reports pointing towards other paths, because reality is dynamic and, most of the time, it is contradictory, as follows: "the size of the classroom would make it possible to have different arrangements, but we did not observe the diversification of simultaneous activities, except for the free playing time" ${ }^{10}$ (E1, own translation).

There are many descriptions indicating the importance of routine to organize children and teachers' experiences. We have noticed that routine in some classes is understood in a quite different way from that pointed out in other investigations that highlight a static and predicted route, whose moments "happen in an ordered way and when the passage from one period to the next seems to be marked by lack of a language capable of reconstructing and recalling experienced times"11 (RICHTER; VAZ, 2010, p. 682, own translation). Actually, the idea is to encourage debates, narratives and memories.

7 In the original: "A professora monta uma tenda na sala para as crianças brincarem de caverna. Além disso, ela ia acompanhando o movimento das crianças, ou seja, observando e apoiando as brincadeiras das crianças como, por exemplo, quando aproximava um colchonete e um tecido para ser a cama de um grupo de crianças que brincava de cuidar o neném, davam comidinha, iam ao mercado etc. Também foi observado a monitora perceber o movimento de um menino e ajudá-lo a montar com cadeiras o que seria inicialmente seu carro. Ele e ela foram colocando cadeiras uma ao lado da outra. A monitora disse que iria encontrar uma "direção" para o carro. O carro virou um ônibus e outras crianças aderiram à brincadeira. O menino criador da brincadeira dizia que ia para o Centro, que tinham que se apressar."

8 In the original: "O berçário é montado com livros e brinquedos (comprados e produzidos pelas professoras) que estimulam os sentidos das crianças (exploram som, cor, textura, forma). As crianças exploram esses materiais livremente e em parceria uns com os outros. No chão da sala há tapete, almofadas e uma boia grande que estimula o movimento das crianças."

9 In the original: "elas estão habituadas e participam ativamente, estão sempre narrando algo que lembraram, que ocorreu, que estão fazendo".

10 In the original: "o tamanho da sala possibilitaria diferentes arranjos, mas não foi observada a diversificação de atividades concomitantes, com exceção do momento da brincadeira livre".

11 In the original: "vão se cumprindo ordenadamente e a passagem de um período para o seguinte parece marcada pela ausência de uma linguagem capaz de reconstruir e recordar os tempos experienciados". 
The monitor ${ }^{12}$ asked each child to bring his/her favorite toy to school. They formed a circle and placed the toys in the center, the monitor talked with the children and started telling the Bad Wolf story; children participated in the story telling by recalling facts or talking about the character "he was good because he took care of the children"; "no, he was scary sometimes", "he was 'veeeery' hairy") and the conversation went on until the children recalled that the character (in the story) had his favorite toy. After such recall, the teacher asked the children to find out which toy belonged to whom. Based on a playful activity, as children were talking and finding out the toy owners, the monitor kept on making some questions, such as "Why do you like it?"; "What is its name?"; "Who did give you this doll?"; Where do you keep it in your house?".13 (E2, own translation)

Routine seemed to be experienced as important situations in some schools, it would trigger interactions between adults and children. At first, many children are dependent, but later on, they become autonomous due to the help of other children - this autonomy is very important to them. The observation below shows how this process can be creative, happy and funny.

Before the music teacher entered the classroom, when children were anxious for her arrival, the monitor invented a narrative based on the creation of a character "a witch", which is quite appreciated by the children. She said: do you know what, lets scare teacher Joana... a witch gave a magic potion to me and I diiiiied. She dramatized each action and her voice, and fell on the floor. Children joined the game and asked for the magic potion, the teacher pretended to have it in her hands and to give some to the children, they also fell on the floor. The monitor turned the lights off, they whispered and laughed out low. The monitor says: "I think Joana will cry a lot". Joana: "I think I will have to sing a magic sound". ${ }^{14}$ (E3, own translation)

12 In this school, the assistant is called monitor and plays the role of a teacher.

13 In the original: "A monitora pediu que cada criança trouxesse para escola seu brinquedo preferido. Em roda, colocaram os brinquedos no centro, a monitora conversou com as crianças e, aos poucos, foi retomando a história do Lobo Mau Mau, as crianças participaram evocando fatos ou falando sobre o personagem ('ele era bonzinho porque cuidava das crianças'; 'não, ele assustava as vezes'; 'era muuuito peludo') e a conversa seguiu até as crianças lembrarem que na história (já lida para a turma) o personagem tinha um brinquedo preferido. Após essa retomada, lançou o convite para que as crianças descobrissem de quem é cada brinquedo. Num clima de brincadeira, conforme as crianças iam conversando e descobrindo a quem pertenciam os brinquedos, a monitora ia fazendo algumas perguntas, tais como: 'Por que tu gostas dele?'; 'Qual o nome dele?'; 'Quem te deu a boneca?'; 'Em qual lugar na tua casa ele fica?'”.

14 In the original: "Antes da entrada da professora de música na sala, quando as crianças estavam bem apreensivas por sua chegada, a professora inventa uma narrativa com a ideia da personagem bruxa, que é muito apreciada pelas crianças. Ela diz: 'já sei, vamos assustar a prof. Joana... a bruxa me deu uma poção mágica e morriiiiii'. Dramatizando cada ação com o corpo e voz, ela cai ao chão. As crianças entram na ideia da brincadeira e pedem também a poção mágica, ela simboliza ter uma taça na mão e dá na boca das crianças, elas deitam-se ao chão. A monitora apaga a luz, eles murmuram e riem baixinho. A professora diz: 'acho que a Joana vai chorar muito'. Joana abre a porta, a monitora diz 'socorro, Joana, a bruxa esteve aqui e envenenou toda a turma!'. Joana: 'acho que vou ter que cantar uma música mágica'. 
The routine counts on the time to play in the backyard, which is quite large, has trees and toys. After leaving the backyard, children went back to the classroom where they found many toys available. While they were playing in the classroom, groups with 3 children were going to take a shower. This sequence was followed during 2 observation days. Before going to the backyard, children played with Lego parts, which had been recently acquired by the city hall. ${ }^{15}$ (B5, own translation)

The support by different materials was essential to broaden children's experiences. The following objects are co-authors in the context: books, characters in told stories, drawings, games, fabric, among other objects that enrich the interactions and experiences lived in schools' routines.

Children develop drawing activities about volcanos in the classroom, a volcano is shaped with clay and exposed on a shelf - as children's production. ${ }^{16}$ (A5, own translation)

The teacher placed paper ( $40 \mathrm{Kg}^{17}$ ) on the floor and children had pencils and crayon to draw. While they were drawing, the teacher was interacting with them about their drafts. We also saw papers hanging on the walls to perform this same activity, and it shows that this is a common activity proposed by the teacher. ${ }^{18}$ (B4, own translation)

The class often organized an information panel on which children shared their works and activities developed throughout the year. It was possible observing the use of different resources and languages in different periods as a way of expression. ${ }^{19}$ (D3, own translation)

15 In the original: "Há na rotina um horário no pátio externo que é bastante amplo, com areia, árvores e brinquedos em bom estado. Ao sair do pátio as crianças foram para a sala onde estavam disponíveis brinquedos diversos. Enquanto brincavam na sala, grupos de três iam saindo para o banho. Essa sequência ocorreu nos dois dias de observação. Antes do pátio as crianças brincaram com o Lego, material recém-adquirido pela prefeitura."

16 In the original: "Na sala, há atividades de desenho das crianças sobre vulcões e um vulcão esculpido com argila em uma das estantes - como uma produção das crianças."

17 Paper resistant to paint, dimension $66 \mathrm{~cm} \times 96 \mathrm{~cm}$

18 In the original: "A professora colocou papel $40 \mathrm{~kg}$ no chão e as crianças receberam lápis de cor e hidrocor para desenhar. Enquanto desenhavam, ela interagia com as crianças sobre os rabiscos que faziam. Também vimos nas paredes da sala papéis com essa mesma atividade, fixados na parede da sala, o que mostra que essa é uma proposta que a professora costuma fazer."

19 In the original: "A turma organiza com frequência o mural informativo, no qual as crianças socializam trabalhos e atividades dos projetos desenvolvidos ao longo do ano. Em períodos diferentes, foi possível observar o uso de diferentes recursos e linguagens como forma de expressão." 


\begin{abstract}
It was observed that children were free to seek paper in the cabinets, as well as drawing and/or writing materials, whenever they wanted to. Besides, children were asked to manipulate colorful glue to reproduce a scene or a character from the book read by the teacher; A Polegarzinha (Thumbelina) by Hans Christian Andersen. ${ }^{20}$ (E6, own translation)
\end{abstract}

We found a box with letters of the alphabet and games to assemble on the shelf. There were also literature books, magazines and LEGO didactic books [...]. There were different materials such as glue, scissors, paper, crayon, pots filled with numbers and letters, among others. ${ }^{21}$ (B1, own translation)

Mutable spaces, corners to encourage playing and interactions, free access to explore toys and materials, the possibility to set different groups, different materials and toys - including the ones made by the teacher -, space for the promotion of autonomous actions and creative interventions to broaden a symbolic game are possibilities of actions, interactions and interlocutions between children and adults.

Similar to the reports, pictures report the spaces inhabited by children and adults in schools, they depict the diversity of each class, but also evidence the closeness between schools in different Brazilian regions. Images of babies and children playing with blocks, reading books in different places, listening to storytelling in the classroom or in the library, painting, drawing with chalk in the backyard, seating on the floor, on a circle or in groups, are recent. They show that nursery children have their objects identified with their names and a handbook for communication with family members. There are several descriptions about them, as in the following report, "there are many notice boards about the children, they are used in communications with the team (menu, physiological needs chart, food chart, among others). There is also a notice board to the parents" 22 (B3, own translation).

Babies are on the floor over cushions in most pictures, or toddling, exploring, but there are pictures in which they are on the carts, waiting to be fed. Panels and portfolios present babies and children's pictures in their activities in daycare - subtitles inform about what is depicted. 
Researchers took many pictures from the panels exposing the drawings in the pre-school classes, from the presence chart and from the registers with names, calendars, birthday month, collective history records, poems, lists and recipes. Some classrooms presented a lot of information on the walls, besides images of media characters and stereotyped drawings along with children's productions. There were many records of children playing with 'bingo of names', reading, writing their names and, although in just few schools, there were children using notebooks, seating on chairs and at individual desks. The alphabet was available in almost all classrooms, including in daycare classes. Children at all ages were depicted reading, but pictures of children writing stand out in pre-school, mainly when it comes to the presence of chairs and desks. Panels showed the written practices. Let's see the description of a pre-school classroom:

The productions of two groups that use the same classroom were hanged on the walls. There were notice boards (calendars, the name of the assistant of the day, calendars of different shapes, warnings, massages, news), the record of assignments performed with the alphabetic writing system (search for letters, search for words, rimes, the alphabet), the record of assignments by the school as a whole (activity reports, pictures, images). All the exposed materials were placed at children's height. ${ }^{23}$ (D5, own translation)

This cut between daycare and pre-school calls the attention, because most assessed classes are in schools exclusively focused on early childhood education. Some images made us think whether elementary school would actually be in a different building.

Pictures show what called researchers' attention in the field. The choices they made, and the captured images opened discursive room to outspread the reality and also to reflect about it, since they reported conceptions either by the investigated teachers or by the researchers themselves. Images of the spaces and materials made us realize that the practices enable more relaxed and guided moments, as well as innovative and creative moments, and common and cliché ones. Between light and shade, the cracks seem to point towards a movement that seeks positivity and correct actions. White, black and brown children; boys and girls smiling, reading, drawing, playing, concentrated, engaged. Would they be the core of propositions advocated by DCNEI? Spaces and materials found in most of the investigated classes seem to have the potential to become environments-processes in constant and mutual affectation and, consequent,

23 In the original: "Em todas as paredes há produção dos dois grupos que fazem uso da sala. Há cartazes informativos (calendário, ajudante do dia, coletânea de formatos diferentes de registro dos calendários, avisos, bilhetes, notícias), registro do trabalho que é feito com o sistema de escrita alfabética (pesquisa de letras, pesquisa de palavras parlendas, alfabeto) registro do trabalho que é desenvolvido no projeto coletivo da escola (relatos das atividades, fotos, imagens). Todos materiais expostos nas paredes são colocados na altura das crianças." 
to change. However, we argue: What are the times opened to interaction and games? How does the action of adults potentiate and support the interlocutions? How do children experience the practices performed at school?

\section{INTERACTIONS AND INTERLOCUTIONS}

The principle according to which materiality is 'signic' leads to the understanding that it enunciates a discourse headed to the one who answers. The answer, based on Bakhtin (1992), is a replication, the result from understanding. Therefore, the aforementioned author encourages the understanding of interactions as interlocutions of an active and creative subject who constitutes, and is constituted by, this process of mutual affectation. There is a complexity in this subject/world interaction, and vice-versa. That is how the appropriations and productions by subjects take place within an intense dialogical process and the richness of contexts is not reduced to quantity, but to the quality of the relationships, in other words, to the possibilities to produce meaning. "Quality that becomes effective through the dialogic, active and responsive presence of the other. Thinking about the educational context - which is in children and children are in it - demands one to take into account this relational complexity" 24 (CORSINO; GUIMARÃES, 2017, p. 72, own translation).

According to Vygotsky (2001), this production of meaning refers to all psychological elements that operate in conscience by the word, i.e., the meaning is given not just through cognitive comprehension, but also in integration with affection and emotion. Thus, this relational complexity included both repertoires and bonds, affections and mutual cooperation sense. Accordingly, we understand adults in the relationship with children as important dialogic agents who take indirect actions by organizing the spaces, materials and propositions. But they also interact in an indirect way in interlocution processes by observing, asking, listening and replicating.

The role of early childhood education teachers in the relationship with children is essential, because the teacher is the one who plans and organizes the spaces and materials, who optimizes time, articulates different voices, puts viewpoints in interaction, favors ludic-symbolic activities to children, suggests different ways of expression, among other actions. The role played by the teacher is not reduced to introduce the world to newcomers (ARENDT, 1997), but to make it possible, to favor, to support the conversation between children, and between children and teacher, within their relationship with knowledge and awareness of the world. Based on such assumptions, we elaborated a protocol for the observations, which encompassed questions that invade and refine the sight over the interactions-interlocutions. There were also questions about the presence of other languages - music, body, visual arts - to draw a broad panorama of the work developed in the language field, since it is essential that 
children have the opportunity to develop different ways of expression in early childhood education. Therefore, it is mandatory to seek balance among these ways of expression. We also elaborated questions about the existence of a time to play games managed by children themselves, and by the teacher, in the class routines.

It was possible to observe the presence of many interactive practices, since most of the addressed items overcame the percentage of affirmative answers by $70 \%$, some reached $100 \%$, when teachers were asked to look at the children as they address them and to call them by the name. The lowest rates refer to the following items: the teacher encourages children to explore musical instruments and other sound objects (only 33.3\%); the teacher tells stories using different resources (37\%); and besides literature books, the teacher reads informative texts to support children's curiosity $(25.9 \%)$ - these are all specific items. We know the limits of observation for a pre-determined time, and it was not possible to witness all these items happening during this time. However, based on the answers, most teachers seem to establish a dialogic relationship with the children and this finding may have been one of the factors to justify the nomination of these teachers by the interviewed school principals. So, how did these interactions-interlocutions happen? What are the practices standing out in the researchers' reports?

The records show that the time for conversation often takes place when children are set on a circle, this is the time when teachers make more systematic interventions in children's oral production. The circle is where the teacher informs, circulates different narratives, tell stories, explains, corrects, talks about countless experienced situations, organizes children's speech turns and encourages them to express themselves in clearer ways.

In the discussion about the written report, the teacher recalled the visit of an old combatant, the teacher asked; "what are we going to draw today?" One child answered: "are you saying that there is... that there is... that Noa has stumbled in a hole on the sidewalk". The teacher took from the child's speech and addressed the group: "we are going to draw what is written in this part of the text. And at this part of the text is written that Noa stumbled in the hole on the sidewalk. That's it. Very good" - the discussion happened during the conversation in the circle. As already mentioned, the conversation circle is a very common pedagogical strategy in the observed practices. They are the moments when reports about experiences are organized, when different discussions are set and combined, when works are planned to develop projects. ${ }^{25}$ (D5, own translation)

25 In the original: "Na discussão sobre o relato escrito que a professora apresentou à turma sobre a visita à pracinha, a professora pergunta: 'O que vamos desenhar hoje?' Uma criança responde: 'está falando que tem... que tem... que o Noa 
Many reports present interlocutions between teacher and children, they are related to the time of events. Present, past and future are addressed in different ways. With respect to babies, many narratives followed the actions, i.e., narratives aimed at giving meaning to events happen in the moment of the interrelation. Past is approached to recover experienced situations, this is a way to recall memories, to take trajectories back and to go on with the propositions. Future explains and introduces to children what will be done, it is a way to insert the children in the educational process. These daily narratives emerge as an important resource for the production of shared meanings:

The teacher, as well as the monitor, talk a lot with the babies, they use a language to tell what is happening, and interact with the babies through such languages. During diaper changing they talk to the babies and tell them what is about to happen (for example, put the pants on), they exchange smiles, and sometimes, they sing to the child. ${ }^{26}$ (E4, own translation)

During the time to recall what was done in the day before, during cake baking, while children were saying what they had done, the teacher completed the information. A child called the attention to the panel where they had written the cake recipe and she read the panel and encouraged the children to read along; she clarified what they were saying and made questions, as well as stimulated the oral expression of the whole group. ${ }^{27}$ (B5, own translation)

During the visit to the library, when children were getting to there, the monitor anticipated what was about to happen: "Today we will listen to a story and, after, we will see who is going to take the book home. Each one will choose a book". ${ }^{28}$ (E2, own translation)

\footnotetext{
tropeçou no buraco do passeio'. A professora retoma a fala da criança, se dirigindo também para o grupo: 'Nós vamos desenhar o que está escrito nessa parte do texto. E nessa parte do texto está escrito que o Noa tropeçou no buraco do passeio. É isso mesmo. Muito bom' - a discussão aconteceu numa roda de conversa. Como já foi mencionado, a roda de conversa é uma estratégia pedagógica muito comum nas práticas observadas. Nelas se organizam relatos de experiências, discussões diversas, combinados e planejamentos de trabalho no desenvolvimento dos projetos."

26 In the original: "A professora, assim como a monitora, conversa bastante com os bebês, utilizando a linguagem para ir narrando o que está acontecendo, além de interagir com os bebês por meio dela. Durante a troca, vai conversando, antecipando o que vai fazer (ex. colocar calça), trocando sorrisos e, às vezes, cantando."

$\mathbf{2 7}$ In the original: "Durante a retomada do que foi feito no dia anterior na produção do bolo, enquanto as crianças diziam o que havia sido feito, a professora complementava as informações. Uma criança chamou logo a atenção para o cartaz onde haviam escrito a receita do bolo e ela foi lendo o cartaz, sempre estimulando a participação das crianças, clareando o que diziam e formulando perguntas e incentivando a expressão oral de todo o grupo."

28 In the original: "Na visita à biblioteca, quando as crianças chegam no espaço, a monitora conversa antecipando o que irá acontecer: "Hoje nós vamos ouvir uma história e, depois, vamos ver quem vai levar livro para casa. Cada um vai escolher um livro'."
} 
There were moments when interactions between teachers and children would happen in imaginary situations, within a connection of gestures, words and a ludic-symbolic game:

\begin{abstract}
A baby takes the basket with little pans and other kitchen devices, takes a glass and seats close to the wolf doll made out of socks. The teacher, in a certain moment, interferes saying; "Let's put some juice in the glass?" (she pretends to drink from the glass). Next, she offers the glass to the wolf doll and says: "Let's sing a wolf song?", while she sings, she moves the wolf doll around while the baby follows the doll with the eyes and moves the body and mumbles. ${ }^{29}$ (E1, own translation)
\end{abstract}

When the child's linguistic form remained little articulated, researchers observed moments when teachers gave back to the child the sense of being understood, therefore, they enriched their communication skill.

Some babies are exploring the basket of treasures, the teacher stands up and walks towards the diaper changer, on her way she sees Giovana, and by noticing that she looks and mumbles, the teacher gets down to her and asks: "What is that Gi?", while she seats and extends her hands towards the baby, who gets closer to her and seats on her lap. The teacher bends (back and neck, and puts her ears close to the baby) to listen what the baby is whispering. Next, the teacher talks to the monitor and says: "She was saying something, and I could not understand, then I called her to talk closer to me. She had peed in her pants. In another time, the teacher recalls "Oh yes, let's go Leonardo!"30 (E1, own translation)

The teacher asked: "Who wants to be a ballerina?" $A$ boy said he did not, and she asked: What do you want to be? He said "superhero". Nobody understood what he said, but she

29 In the original: "Um bebê pega para brincar a cesta com panelinhas e outros objetos de cozinha, e retira um copo, sentase próximo ao boneco de meia do lobo. A professora, em determinado momento, interfere dizendo 'Vamos colocar suco?' (faz de conta que coloca e que bebe). Em seguida, faz que oferece suco ao lobo e diz: 'Você quer lobo?' O bebê faz também, aproxima o copo da boca do lobo. Um pouco depois, a professora convida: 'Vamos cantar música do lobo?', enquanto canta, mexe com o boneco do lobo e o bebê a acompanha com olhar, movimenta o corpo e balbucia."

30 In the original: "Alguns bebês estão explorando o cesto dos tesouros, a professora levanta-se e dirige-se ao trocador No caminho encontra Giovana e, ao perceber que ela a olha e balbucia, a professora abaixa-se e pergunta 'O que, Gi?', enquanto vai sentando e estendendo a mão na direção da bebê, que se aproxima e senta no colo da educadora. A professora se inclina (costas e pescoço colocando ouvido mais perto dela) para ouvir o que a bebê sussurra. Depois, a professora, ao conversar com a monitora, fala: 'É que ela estava falando alguma coisa e eu não estava entendendo, aí eu chamei ela para falar perto de mim. Era xixi.' Em outro momento observado, a professora fala: 'Vamos chamar o lobo para ouvir uma história', Leonardo balbucia e sorri, a professora retoma 'Ah sim, vamos, Leonardo!'." 
insisted until she could understand what he wanted to say and repeated the word to the group. ${ }^{31}$ (B2, own translation)

Music, in its different forms, was the language mostly observed in the investigated classes. Children in the nursery move around in the rhythm of the music, teachers sing to them at different moments to achieve different goals: tell stories, make children observe something, stop their crying, make them sleep, play, to call characters in a story, among other factors. Music is the background, it broadens the repertoire, it marks time and the routine activities, as well as is used to suggest tasks and actions:

During the observation days, in the afternoon shift, an instrumental song was paying at low volume. The teachers also reported to try to diversify the genres (classical music, Mozart, lullabies, sons da natureza, nature sounds, animal talking, Palavra Cantada, indigenous songs, among others). There is also a music box available, in which babies pick an animal effect and the teachers sing a song related to the chosen animal. ${ }^{32}$ (E1, own translation)

The teacher also sang songs to set the routine, such as at the time to go for lunch or at the time to tell a story ("nock, nock. Who's that? Come in. It is the story that has just arrived"). At the time to call the names of children in the identification card, the teacher would present the card, ask whose name was that, would say the name and give the card to the child or she would keep it in the box she had brought along with the literature books. At the time to give the card, she would sing: "Your name is... to you I will say. Your name is... and yours I want to know" and would present another card. $^{33}$ (B4, own translation)

31 In the original: “A professora perguntou: 'quem quer ser bailarina?' Um menino disse que não queria e ela perguntou: 'você quer ser o quê?' Ele falou 'super-herói'. Ninguém conseguiu entender, mas ela insistiu até entender o que o menino queria dizer e repetiu a palavra para o grupo."

32 In the original: "Nos dias de observação, em um período da tarde, estava tocando um CD com música instrumental com volume bem baixo. As educadoras também relataram que procuram diversificar os CDS (música clássica, Mozart, acalantos, sons da natureza, coleção de cantigas, conversa de bicho, Palavra Cantada, canções indígenas, etc.). Há também a caixa de música, em que com os bebês sorteiam os bichos de feltro e, então, as educadoras cantam as músicas relacionadas a eles."

33 In the original: "A professora também cantava músicas para marcar a rotina como na saída para o lanche ou no momento da história ("Toc, toc. Quem é? Pode entrar. É a história que acaba de chegar"). Na chamada com cartões com os nomes das crianças, a professora apresentava o cartão, perguntava de quem era o nome, dizia o nome e entregava o cartão para criança ou guardava na caixa que tinha trazido junto com livros de literatura. No momento de entregar o cartão ela cantava: 'O seu nome é ... pra vocês eu vou dizer. O seu nome é ... e o seu quero saber' e apresentava outro cartão." 
Another common form was the relation between music and reading. Stories bring along music, gestures, body movements and are directly linked to the act of reading:

\begin{abstract}
Teachers sing a lot and, slowly, their gestures become more complex, according to them: "we work literature through music, and we use music to work poetry". It is important highlighting that it does not happen as a moment to reproduce gestures, but in a relaxed way, such as an invitation, individual spaces and moments in the relationship with the babies. About these moments, we have observed that babies liked them and felt happy about them, some would shake their bodies in some specific parts of the song (that they seemed to have known), they would pay attention and react to them with some gestures and an expression of happiness. ${ }^{34}$ (E1, own translation)
\end{abstract}

Music seems to trigger moments of interaction, it sometimes is bond to words, or lack words, but sets interpersonal bonds through fruition; however, it enters the aesthetical, ethical and political space of art.

The research has shown that literature is often present in the observed classes. Teachers read or tell stories to the children in all of them. Books were accessible in the classroom, they were organized in libraries opened to the children, they were stored in low shelves, baskets and boxes, they circulated in the hands of children and adults, they were read in the classroom, hallways, libraries, in the conversation circles, over cushions on the floor, in big groups and in small ones, as well as individually. They were taken home in customized bags to be read to the family. Some pictures show well-organized libraries with a broaden inventory of books, as well as puppets and other dolls, stages, TV, sound system and materials that can expand the reading skills. Traditional stories, a 'Ciranda' - such as the three Little Pigs, Miss Cockroach, Little Red Riding Hood -, and stories written by renowned Brazilin writers such as Sylvia Orthof, Ziraldo, Ana Maria Machado, and by foreign writers were mentioned in teachers' observation reports. We can state that there are books in the investigated classes - most of them seem to be good and to be in good shape - that are often read. However, it was observed that there is a contrast between reading to, and with, babies and children in small daycare centers, and reading to children in pre-school.

\footnotetext{
34 In the original: "As educadoras cantam bastante e, aos poucos, vão complexificando gestos, segundo elas: 'Trabalhamos a literatura com as músicas, e com as músicas trabalhamos poesias'. Cabe destacar que isso não ocorre como momento de reprodução de gestos, e sim de maneira tranquila como um convite a cantar, em espaços e momentos individuais na relação com os bebês. Sobre esses momentos, observou-se que os bebês gostavam e sentiam-se contentes, sorrindo, alguns acompanhavam balançando o corpo, e em partes específicas de canções (que pareciam já conhecer) ficavam atentos participando com reações e alguns gestos e expressão de alegria."
} 
Daycare: The reading and storytelling activities stand out in this group. It was observed that they are part of its routine: children seat when the teacher shows the book she is about to read. In a different moment, a child takes a book and shows it to the teacher, as if the child was asking her to read it. The teacher understands the child's gesture and starts reading the book right the way. The reading planning elaborated by the teacher also stood out, because it encouraged children to interact with the text. For example, in the book "Where is Pedrinho?", the character hides behind a tree and only shows off part of his body until, finally, he shows his whole body. Then, the teacher asks: "Where is Izabela's foot? And where is Ana Clara's?", and she goes on, following the sequence of the book. ${ }^{35}$ (B3, own translation)

Pre-school: After finishing the story, the teacher starts to make questions about its plot and characters. Children tell what they remember, what they have understood, their impressions. She questions about the features of the characters; she "corrects" some speeches that distort the story and controls the restless children. She complements the conversation circle. She asks: How do we write the word "cockroach"? She fixes metallic letters on a magnetic panel positioned on her lap. She takes the letters from a little bag attached to the chart and assembles the word, she asks what is the letter that comes next, and which one stays at the end of the word. The word "cockroach" is quickly written with watercolor pen. Then, she tells the students that they will draw the "cockroach"; children run fast to the desks.

The teacher shows the sheet of paper with the assignment; some children walk around the classroom. The teacher helps them. Children do their drawings (the teacher returns to the activity; she explains to the children what is to be drawn and to write the name of the "cockroach"). ${ }^{36}$ (A3, own translation)

35 In the original: "Creche: Destaca-se neste grupo a atividade de leitura e contação de histórias. Foi observado que esta faz parte da rotina: as crianças sentam quando a profa. mostra o livro que vai ler/ contar. Em outra situação foi observado que uma criança pega um livro e insistentemente mostra a profa. como se pedindo para que ela lesse. A profa. entende o gesto da criança e lê o livro em seguida. Também destaca-se o planejamento da leitura feito pela professora ao compor a caixa surpresa com objetos que dão suporte a sua contação. Durante a leitura de histórias também estimula as crianças a interagir com o texto. Por exemplo, no livro Cadê Pedrinho?, o personagem fica atrás de uma árvore e vai mostrando apenas partes do seu corpo até, finalmente, aparecer de corpo inteiro. A professora vai, então, perguntando: 'cadê o pé de Isabela? E o de Ana Clara?' e, assim por diante, seguindo a sequência do livro."

36 In the original: "Pré-escola: Ao concluir a história, a professora começa a fazer perguntas sobre seu enredo e personagens As crianças vão falando o que lembram, como compreenderam, suas impressões. Ela vai questionando-os sobre as características dos personagens; 'corrige' algumas falas que distorcem a história, ao mesmo tempo que contém as crianças mais inquietas. Ela elogia a roda. Pergunta: como se escreve a palavra baratinha? E vai colando letras metálicas em um quadro magnético que está no seu colo. Ela vai pegando as letras em uma bolsinha que tem junto ao quadro e vai mostrando a palavra, perguntando qual a letra que vem depois, qual vem no final. Monta bem rápido a palavra BARATINHA, com hidrocor. Então, fala que vão agora desenhar a Baratinha; as crianças correm rápido para as mesas.

A professora mostra o papel com a tarefa e explica o que irão fazer: escrever o nome da história e, depois, desenhar. As crianças vão se organizando para fazer a tarefa; umas andam pela sala. Ela vai ajudando-os. As crianças vão desenhando (a professora vai retomando, falando o que é para desenhar e escrever o nome da baratinha)." 
This last event presents a sequence found in reports of many classes: storyreading to the class followed by comprehension questions, by questions about the time sequence of events in the story and of information in the verbal and/or visual text. Next, the teacher highlights a word in the story for the written microanalysis and, at the end, there is a graphic task related to the story, which uses to be a drawing or writing a copy of the word. The reading proposition clearly aims at checking a linear comprehension - any deviation must be corrected - and at literacy. There is a clear disruption due to the fictional game, to the symbolic space of imagination and creation.

We have noticed the relapse of observation over activities related to students' identification in the reports. This identification is carried out with photographs in the daycare centers. Students identification in pre-school lies on having children writing their names in their identification cards. These cards are used in many reading activities, to identify letters, to compare sequences of letters, to count the number of letters and syllables.

Daycare: The teacher takes puppets made of popsicle sticks and pictures of children for student identification. The teacher asks children to check who is at school: "Who did come to school today?", and shows a picture to the children, who say the name of the classmate in the picture. Children like to be recognized on the picture; they smile when they point at the child on the picture. When the child is not at school, she asks the children where this student might be. Because she knows the reason of the child's absence, the teacher says: "she went out with her mother". A child says: "by bu". The teachers says: "yes, she went by bus to meet her grandmother in Osório". ${ }^{37}$ (E5, own translation)

Pre-school: the initial circle meant a long time for chats/ conversations, children talk to each other - the teacher listens and takes back her turn of speech. The teacher asks if the name Rafael is similar to Natanael. She explores other words with similar sounds. Children say: pastel, Gabriel. Finally, the name Natália. She asks what the name following the sequence NATÁ would be. She asks what name has the same graphic mark: They say Natália and Nataly. She asks Natália if her name has this graphic mark, the girl answers so and the teacher shows it to the whole class: this is Natália's name, it has this graphic mark

37 In the original: "Creche: Na chamadinha, professora pega fantoches confeccionados com palitos de picolé e a imagem do rosto das crianças, convida as crianças para ver quem está na escola. Professora: 'Quem veio hoje?'. Então, pega um dos fantoches na mão e sem mostrar a foto pergunta: 'quem chegou à escola foi?', nesse momento mostra a foto, as crianças dizem o nome do colega. As crianças gostam de serem reconhecidas na foto, elas sorriem tanto ao apontar para quem veio quanto a criança que está na foto. Quando a criança não está na escola, ela questiona onde será que ele (a) está? Por saber do motivo da ausência de uma das crianças, a professora diz: 'ela foi passear com a Mamãe dela'. Uma criança diz: 'de binu'. Prof.: 'sim, ela foi passear de ônibus para ver a Vovó dela lá em Osório'. 
on Tá. The teacher shows another name starting with letter A, she says Ana Júlia and goes on until finding out letter $D$. She asks what letter that is. ${ }^{38}$ (A5, own translation)

Many observation reports present pre-school teachers' dialogues and procedures in practices related to word analysis, such as games to identify words initial and final sounds, to correlate letter and/or syllables to the sound of the word. Researchers were careful in detailing such procedures, as well as the dialogues after a story was read, the chats on the conversation circle about the topic in question, children talking, among others.

The teacher suggests the oral word analysis and relates it to the written form (surprise box). Through these words children have the opportunity to observe and learn aspects of alphabetic writing system number of syllables in the oral word, number of letters, identification of letters composing the written word, initial and final letters, among others). Written word production and the procedures for word analysis (letter identification, comparison of the number of letters and syllables, syllable identification and segmentations, among others) sets the children's routine and establishes the methodological pathway in teachers' practices. ${ }^{39}$ (D5, own translation)

The teacher says: Which one of these is art? The child holds ATIVIDADE - ARTE (ACTIVITY - ART). The teacher asks how it starts, and children say: $A$; and how does it end? Children say: E. "And now? How will we know which one ART is?", The teacher recalls. A child said that it was the shortest word - the child with the two cards says while looking at the words. (Just a tip: think about the letter that comes next). They finally realize and say: $R$, after the $A$ in $A R T T^{40}$ ( $A 5$, own translation)

38 In the original: "Pré-escola: A roda inicial foi um longo momento de diálogo/conversa onde as crianças falam com cada um - ouve, retoma suas falas. No nome de Rafael, a professora pergunta se termina igual a Natanael. Explora outras palavras com som semelhante. As crianças falam: pastel, Gabriel. Aparece, enfim, o nome de Natália. Ela pergunta qual nome será ao aparecer a sequência NATÁ. Pergunta qual nome tem esse 'acento': elas dizem Natália e Nataly, ela pergunta à Natália se o nome dela tem esse acento, ela diz que sim e a professora retoma com todos: 'esse é o nome Natália, tem esse acento para ficar forte o Tá'. A professora mostra outro nome começando com a letra A, ela diz Ana Júlia e segue mostrando e ela descobre o D. Pergunta que letra é essa."

39 In the original: "A professora propõe atividades de análise da palavra oral, relacionando-a à sua forma escrita (ex. caixa de surpresa). Através delas as crianças têm oportunidade de observar e apreender aspectos do sistema de escrita alfabética (quantidade de sílabas da palavra oral, quantidade de letras, identificação das letras que compõem a forma escrita das palavras, letra inicial e final, etc.). A produção de escrita de palavra e os procedimentos de análise das palavras (identificação de letras, comparação do número de letras e de sílabas, identificação e segmentação de sílabas, dentre outros) que constituem o cotidiano das crianças concretizam o caminho metodológico da prática da professora."

40In the original: "A professora pergunta: 'qual desses é arte?' A criança pega ATIVIDADE - ARTE. As professoras perguntam como começa e as crianças dizem: A; 'e como termina?' As crianças dizem: E. 'E agora? Como vamos saber qual será ARTE?' A professora lembra: 'uma criança falou que era a palavra menor'; a criança com as duas fichas olhandoas fala as palavras. ('Dou uma dica: pensar qual a letra que vem depois'). Até que elas descobrem e falam: $R$, depois do A de ARTE." 
We have observed that practices related to the literacy process in pre-school classes were understood as good examples of reading and writing by some researchers, as described below:

\begin{abstract}
There are many good examples of reading and writing practices in the classroom. Besides the daily activities focused on collective writing in the Daily Agenda and in the Assistant of the Day, we also observed two interesting games. One of them was called "bingo of names", played with cards with the names of typical Saint John's Day food (corn, mungunzá, canjica, among others). The teacher calls the name of a letter and takes it from the bag; the children would cut the corresponding letter from their cards. The other game was the Literacy Games box, which is distributed by the Ministry of Education to elementary schools. The game is a Bingo based on the sounds of the letters; it aims at making children pay attention on the sounds of the words. In this case, they must pay attention on the initial sound of the word called by the teacher (for example, "mackerel") and say if it matches with the initial sound of the picture seen on the bingo card. Therefore, this game stimulates the phonological awareness, which is an essential skill for literacy. ${ }^{41}$ (B1, own translation)
\end{abstract}

A question brought by the event does not concern the propositions themselves, but the meaning given to them, to the time they demand during a school shift, to the choices that can narrow or broaden the symbolic, linguistic and cultural horizons of children. The contrast between daycare and pre-school, and the close relation between pre-school and literacy observed in the research, highlights the relationship between daycare and mandatory education, and between early childhood education and elementary education.

\title{
FINAL CONSIDERATIONS: AN OPEN DEBATE
}

Based on the present findings, it is essential to carry out in-depth reflections about this complex relationship within the educational system. Moss (2011)

\footnotetext{
41 In the original: "São muitos os bons exemplos de práticas de leitura e escrita nessa sala. Além das atividades diárias de escrita coletiva da Agenda do dia e do Ajudante do dia, já citadas aqui, foram observados dois jogos bastante interessantes. Um deles foi o 'bingo de nomes' em que as cartelas eram nomes de comidas típicas do São João (MILHO, MUNGUZÁ, CANJICA, etc.). A professora chamava o nome de uma letra retirando de um saquinho e as crianças riscavam a letra correspondente em sua cartela. O outro jogo está na caixa de Jogos de Alfabetização, distribuída pelo MEC para escolas do ensino fundamental. O jogo é o Bingo de sons e o objetivo é levar as crianças a prestarem atenção para os sons das palavras. Nesse caso, elas devem observar o som inicial da palavra chamada pela professora (por exemplo, 'MELECA') e ver se combina com o som inicial das figuras que estão em sua cartela. Trata-se, portanto, de um jogo que estimula a consciência fonológica, uma habilidade essencial para a alfabetização."
} 
mapped, analyzed and classified the way how different members of the Organization for Economic Co-operation and Development (OECD) understand such relationship. Researchers wander about factors influencing, for example, the increase in the number of children enrolled in education systems before the mandatory education period; the correlation between education birth to learning performance at school; and the argument that the most productive investment in education is the one made in children below the mandatory education age (MOSS, 2011). This author states that four types of relationships stand out in these countries, namely: children's preparation to school; distance from these stages; school preparation to children and; finally, the search for convergence based on debates and collective construction. The collective construction aims at strong and balanced partnerships set by teams working in common projects. Moss (2011, p. 146) concluded that, despite the positive factors suggesting when this relationship is closer and more collaborative, there is the risk of having early childhood education become a mere preparation stage. This process should take into account the specificities of children and of this period, since "this relationship is not just a matter of proximity, but also of power" (own translation ). ${ }^{42}$

The sense of children as historical subjects who are active culture and competence producers gained room in field studies, in documents issued by the Ministry of Education. DCNEI (2009) reinforces such concept and puts children in the center of the educational proposition. It means that propositions about early childhood education must result from teachers' observations about the games, talks and questions by children. The logic in this matter does not lie on pre-established contents, which come from outside, to be taught, but on the application of experiences, repertoires and knowledge of children based on their interests - in a contextualized and articulated way. This is the very core of our questions: to which extend, mainly in pre-school, has one kept children in the center of the proposition? How has the power exerted by elementary school been influenced by early childhood education?

The presented collections point out the richness of this research field and the conquests concerning practices closer to the discourse that has been developed in the last few years. Results prove that some conditions are essential to develop good reading and writing practices - expertise, qualification, work shifts in the same institution, regular meetings to collective work planning and organization, smaller number of children per classroom in comparison to elementary school. It was observed that teachers and children read a lot: daily reading, books accessible in the classroom, books circulating on children's hands, book read through different ways at school or at home, book organized in libraries that are visited by the children. Reading and writing practices in daycare classes have a ludic-symbolic profile, they are connected to music and to other language types. There are many records in pre-school classes evidencing the 
teacher figure as the scribe of different narratives of children, but observations have shown more directive practices based on contents related to literacy itself, practices concerned with letter identification, to the identification of the initial and final sound of the words, to practices closer to the ones that take place in elementary education.

Finally, although we acknowledge that observation time is limited and that activities performed do not limit positivity, it depends on the project that substantiates activities with the children, and on the space and period for the activities (therefore, we can state that the 27 schools seek an identity to early childhood education in the organization of spaces and materials, in interactions and interlocutions), on the dialogic form teachers listen to children, on the work developed with the projects, which seem to have prevailed in the classes. However, there is a contrast between daycare and pre-school, and it makes us think that such mandatory education should be the gatekeeper of reason, based on scientific, logical and sequential thinking. Thus, while daycare seems to seek reinventing creativity, we can ask about where pre-school is heading to: will it take the way of magic, myth, creation and fruition or will it be incorporated to the ways of reason? The debate remains open.

\section{REFERENCES}

ABRAMOWICZ, A.; TEBET, G. G. de C. Educação infantil: um balanço a partir do campo das diferenças. Proposições, v. 28, Supl. 1, p. 182-203, dez. 2017.

ARAÚJO, V. C. de. O tempo integral na educação infantil: uma virtude pública? Cadernos de Pesquisa em Educação, Vitória, v. 19, n. 42, p. 13-28, jul./dez. 2015.

ANDRADE, E. R.; NUNES, M. F. R.; FARAH NETO, M.; ABRAMOVAY, M. (org.). Perfil dos professores brasileiros: o que fazem, o que pensam, o que almejam... Pesquisa Nacional Unesco. São Paulo: Moderna, 2004.

ARENDT, H. Entre o passado e o futuro. São Paulo: Perspectiva, 1997.

ARTES, A.; UNBEHAUM, S. Escritos de Fúlvia Rosemberg. São Paulo: Cortez, 2015.

BAKHTIN, M. Marxismo e filosofia da linguagem. São Paulo: Hucitec, 1992.

BONDIOLI, A.; MANTOVANI, S. Manual de educação infantil: de 0 a 3 anos. Porto Alegre: Artmed, 1998.

BOURDIEU, P. 0 senso prático. Petrópolis: Vozes, 2009.

BRASIL. Ministério da Educação. Secretaria de Educação Fundamental. Política de Educação Infantil: proposta. Brasília: MEC/SEF/Coedi, 1993.

BRASIL. Ministério da Educação. Conselho Nacional de Educação. Câmara de Educação Básica. Resolução $n^{\circ} 5$, de 17 de dezembro de 2009. Fixa as Diretrizes Curriculares Nacionais para a Educação Infantil. Brasília: MEC, 2009.

BRASIL. Ministério da Educação. Secretaria de Educação Básica. Contribuições para a política nacional: a avaliação em educação infantil a partir da avaliação de contexto. Curitiba: Imprensa/UFPR; Brasília: MEC/SEB/Coedi, 2015. 
CAMPOS, M. M. Educar e cuidar: questões sobre o perfil do profissional da educação infantil. In: BRASIL.

Ministério da Educação e do Desporto. Por uma política de formação do profissional da educação infantil. Brasília, 1994.

CAMPOS, M. M. Entre as políticas de qualidade e a qualidade das práticas. Cadernos de Pesquisa, São Paulo, v. 43 , n. 148 p. $22-43$ jan./abr. 2013.

CAMPOS; M. M.; CRUZ, S. H. V. Consulta sobre a qualidade na educação infantil: o que pensam e querem os sujeitos deste direito. São Paulo: Cortez, 2006.

CORSINO, P. Infância, linguagem e letramento: educação infantil na rede municipal de ensino do Rio de Janeiro. 2003. 300 f. Tese (Doutorado em Educação) - Pontifícia Universidade Católica do Rio de Janeiro, Rio de Janeiro, 2003.

CORSINO, P.; GUIMARÃES, D. O. Contrastes e deslocamentos na experiência com instrumentos italianos de avaliação de contexto numa instituição da rede municipal de ensino da cidade do Rio de Janeiro. RELAdEI Revista Latino Americana de Educación Infantil, v. 6, n. 1-2 Evaluación de Contextos en Educación Infantil, p.71- 81, enero/jun. 2017.

FANFANI, E. T. Consideraciones sociologicas sobre profesionalización docente. Educação \& Sociedade, Campinas, v. 28, n. 99, p. 335-353, maio/ago. 2007.

FREIRE, M. A paixão de conhecer o mundo. Rio de Janeiro: Paz e Terra, 1983.

KRAMER, S.; NUNES, M. F.; CORSINO, P. Infância e crianças de 6 anos: desafios das transições na educação infantil e no ensino fundamental. Educação e Pesquisa, São Paulo, v. 37, n. 1, p. 69-85, jan./abr. 2011.

MOSS, P. Qual o futuro da relação entre educação infantil e ensino obrigatório? Cadernos de Pesquisa, São Paulo, v. 41, n. 142, p.142-159, jan./abr. 2011.

RICHTER, A. C.; VAZ, A. F. Momentos do parque em uma rotina de educação infantil: corpo, consumo, barbárie. Educação e Pesquisa, São Paulo, v. 36, n. 3, p. 673-684, dez. 2010.

ROSEMBERG, F. Políticas públicas e qualidade da educação infantil. In: ARTES, A.; UNBEHAUM, S. Escritos de Fúlvia Rosemberg. São Paulo: Cortez, 2015.

SOUZA, G. de; MORO, C.; COUTINHO, A. S. (org.). Formação da rede em educação infantil: avaliação de contexto. Curitiba: Appris, 2015. v. 1.

VIGOTSKI, L. S. A construção do pensamento e da linguagem. Tradução Paulo Bezerra. São Paulo: Martins Fontes, 2001.

VOLOCHÍNOV, V. N. Palavra na vida e palavra na poesia: introdução ao problema de poética sociológica. In: VOLOCHÍNOV, V. N. A construção da enunciação e outros ensaios. São CarlosP: Pedro \& João, 2013. p. 71-100.

NOTE: Both teachers are authors and the followed order to mention them was merely alphabetic.

HOW TO REFERENCE THIS ARTICLE

NUNES, Maria Fernanda Rezende; CORSINO, Patrícia. Reading and writing in early childhood education: contexts and practices under debate. Cadernos de Pesquisa, São Paulo, v. 49, n. 174, p. 100-129, Oct./Dec. 2019. https://doi.org/10.1590/198053146109 